Юлія Драгойлович

Белградський університет Філологічний факультет Кафедра славістики julybil@ukr.net
УДК 821.161.2.09

https://doi.org/10.18485/slavistika.2021.25.1.20

Оригинални научни рад примљено 17.05.2021. прихваћено за штампу 17.06.2021.

\title{
ДО ПИТАННЯ ПРО (ДЕ)ГРАДАЦІЮ В ПОЕЗІЇ ТОВАРИША СЕМЕНКА
}

У даній роботі зроблено спробу осмислити творчість Семенка радянського періоду в контексті запропонованої ним та його однодумцями теорії панфутуризму, яка охоплювала такі стадії перебудови мистецтва, як деструкція і конструкція, а також екструкцію та функціоналізм, що становили перехідну, компромісну фазу в цьому процесі. У дослідженні представлено загальні особливості збірок поезії, написаної Семенком у 1928-1931рр., які вказують на те, що футуризм Семенка був явищем концептуальним: Семенко-митець певною мірою «наздоганяв» настанови та прогнози Семенка-теоретика.

Ключові слова: Михайль Семенко, поезія 1928-1931 рр., теорія панфутуризму, екструкція, функціоналізм.

This text represents the attempt at showing the work of Mikhail Semenko from the Soviet period in the context of the theory of Panfuturism which was suggested by the poet and his followers. The theory includes stages of art renewal such as deconstruction, extruction, functionalism and construction. The text supplies the general characteristics of Semenko's poetry collections published in the period between the years 1928 and 1936 which indicate that Semenko's futurism was a conceptual phenomenon: it could be said that Semenko as an artist "caught up" with Semenko's prediction as a theorist.

Keywords: Mikhail Semenko, poetry of 1928-1931, theory of Panfuturism, extruction, functionalism.

\section{Вступні зауваги}

Яскраві сторінки українського футуризму, як і інших авангардних «-ізмів» тривалий час були заборонені, табуйовані, стерті, тож лише 3 90-х рр. XX ст. почався процес реконструкції історії цього надзвичайно цікавого літературного явища. Неоднозначною виступає постать поета і публіциста, засновника і першого теоретика, ідеолога й одного з найвизначніших представників українського футуристичного руху Михайля Семенка на тлі як критичних розвідок його сучасників, так і досліджень останнього чвертьстоліття. У дискурсі 10-30-х рр. минулого століття навколо цієї постаті часто кружляли негативні мітки критиків: «дегенерат», «прокажений», «харциз», «літературне страховисько», «поганий хлопчисько» в українській літературі ${ }^{1}$. Сучасне літературознавство, зважаючи на часову дистанцію, досить захоплено сприймає й інтерпретує сторінки його поезії та публіцистики, присвячуючи більше уваги початковим футуристичним експериментам над формою і змістом у творчості цього автора та епатажності його перших маніфестів.

Об’єктом нашого дослідження стала менш популярна серед літературознавців пізня творчість М. Семенка, зокрема поезія, написана протягом 1928-

\footnotetext{
${ }^{1}$ Див. Ільницький 2003: 29-32.
} 
1931 рр. й уміщена в збірках Сучасні вірші (Харків, Київ, 1931) та 3 радянського щзоденника. Поезї̈ 1930-1931 (Харків, 1932), яка сучасному реципієнту, котрий має змогу споглядати всі особливості літературного процесу в Україні останніх ста років, може видатися своєрідною поетичною деградацією у напрямку до соцреалістичної практики. Така неувага або ж ігнорування ${ }^{2}$ пояснюється як тривалою відсутністю чи ускладненням доступу до друкованої спадщини «забороненого футуриста», так і фактом «віжчуження від сумнівної спадщини «лівих» експериментів у все ще логоцентричному суспільстві посколоніального періоду», за словами відомої дослідниці українського літературного авангарду А. Білої (Біла 2006: 175). Маючи на меті дослідити ідейно-тематичні й жанрові пріоритети, а також поетико-стильові домінанти поезії М. Семенка 1928-1931 pp. у контексті запропонованої ним та його однодумцями теорії панфутуризму, звертаємося до теоретичної іiі платформи, тобто до Семенкових маніфестів та програмних статей, а також послуговуємося дослідженнями семенкознавців $\mathrm{i}$ науковців, котрі займалися вивченням літературного процесу та культурфілософської думки в Україні 1920-30-х рр., - О. Ільницького, А. Білої, С. Павличко, Л. Якимчук, Г. Скляренко, Ю. Стахівської, О. Коцарева, Г. Вдовиченка. Відповідно, доцільним тут буде застосування контекстуально-інтерпретаційного, типологічного методів та деконструкції.

\section{Від теорії}

Маніфестографія є важливим чинником у осмисленні авангардного мистецтва, оскільки його новації складалися поступово, спочатку в теоретичних деклараціях. Т. Коваленко українські літературні маніфести 1920-х рр. порівнює із завданням реклами, оскільки вони «анонсують, привертають увагу та надають інформацію, заохочують публіку до споживання певної літературної продукції» (Коваленко 2015: 72). Історія українського футуризму також починається з епатуючих маніфестів та максималістських програм. Творча діяльність у напрямку від теорії до практики стає легітимізованою. Відтак і опрацювання заявленої нами теми передбачає звернення до засадничих ідей, представлених у науково-публіцистичній спадщині головного теоретика футуристичного руху в Україні.

Г. Вдовиченко, який зосереджується на філософському прочитанні історії українського футуризму, виокремлює три основні умовні етапи еволюції ідейно-теоретичних пошуків М. Семенка: 1) етап розробки «кверофутуризму» $\mathrm{i}$ «лімітивного футуризму» (як «кверофутуризму у філософії)), 1913$1919 ; 2)$ етап розробки «пролетарського футуризму - панфутуризму», 1919$1925 ; 3)$ етап розвитку та популяризації панфутуристичного вчення, друга половина 1920-х рр. (Вдовиченко 2009: 25). Дискурси кверофутуризму та

${ }^{2}$ Наприклад, досить популярний підручник для студентів навчальних закладів Icmopiя украӥнської літератури $X X-$ поч. XXI cm. за редакцією В.I. Кузьменка видано 2013 р., коли вже вийшло декілька грунтовних монографій про український авангард, а також футуризм і творчість М. Семенка зокрема, але у ньому ознайомлення із Семенковою творчою спадщиною обмежене 1921 роком, а пізніший період не висвітлено навіть у загальних рисах (Кузьменко 2013: 117-130). 
панфутуризму суттєво відрізняються і кількісно ${ }^{3}$, і якісно. Зокрема, перший - ігровий, з ефектом виклику, скандалу і боротьби, а другий - просякнутий ідеологією, прагненням абсорбувати партійну риторику; перший несе ідею ствердження індивідуалізму 4 , нехтування національним, намагання деканонізувати будь-який авторитет, другий - констатацію лояльності панфутуристів до влади та доведення відповідності їхньої діяльності принципам будівництва нової держави. Фетишизацію новизни і пошуку в кверофутуризмі на етапі панфутуризму заступає «злиття естетичного і політичного радикалізму» (Павличко 1999: 185), фактично «оптимістичний апокаліпсис» (Біла 2006: 34).

Для формування дискурсу панфутуризму 5 найбільш визначальними $є$ такі публікації М. Семенка: Мистецтво переходової доби (1919), Постановка питання в теорії мистецтва переходової доби (Панфутуристичний маніфест) (1922), Що таке деструкиія? (1922), Мистецтво як культ (1924), До постановки питання про застосування ленінізму на 3-му фронті (1924). Зосередимося на деяких ідейно-теоретичних положеннях, котрі виступатимуть своєрідним фоном, на якому буде представлено основні зміни поетичного слова лідера футуристів.

Щоб проілюструвати основні тези цього дискурсу, пропонуємо такі цитатні блоки.

1. М. Семенко проголошував футуризм передуючою соціалістичній революції «аналогічною революцією в мистецтві», зокрема зауважуючи, що ця течія «не $\epsilon$ щось певне й окреслене», а лиш «акція», «напружений розмах, без суцільности й однородности», і що саме вона «характеризує собою мисте-

${ }^{3}$ М. Семенко кверофутуризм (з лат. querer - шукати, досліджувати) «відрекомендував» лише маніфестом Сам у збірці Дерзання (8 сторінок) й передмовою (як своєрідним продовженням зазначеного маніфесту) до збірки Кверо-футурізм (24 сторінки). Проте різні фрагменти цих коротких текстів часто цитовані (зокрема скандально-символічне речення «Я палю свій „Кобзар“»), вони «випливають» щойно заходить мова про український футуризм або його лідера. Новий етап українського футуризму припав на драматичні події революційного часу, відтак у М. Семенка з'являються «ліві» симпатії і мотиви. У своїх дослідженнях Г. Вдовиченко складає грунтовний список Семенкових публіцистичних праць, у яких розробляється теорія панфутуризму, а також подає супроводжуючий фактаж щодо організаторської діяльності іiі автора (див. Вдовиченко 2009: 25-27). Цей список починається програмною статею М. Семенка Мистеитво переходової доби (1919) і продовжується ще двома десятками програмних документів цього ж автора, поряд із оригінальними розвідками з історії та теорії панфутуризму Г. Шкурупія, О. Полторацького, Л. Скрипника та П. Мельника, що свідчить про тенденцію щодо нарощування ідей в теорії панфутуризму, про намагання розширити, поглибити і закріпити цей дискурс у тогочасному літературному процесі.

${ }^{4}$ Індивідуалізм виявляється і на рівні авторства футуристичної теорії. Дослідники наголошують на такій прикметній подібності української моделі футуризму до італійської: всі етапи руху, його ідеологія та поступ були спрямовані волею однієї людини, зокрема в ІталіїФ. Т. Марінетті, а в Україні - М. Семенка (Скляренко 2017: 76).

${ }^{5}$ А. Біла стисло визначає основні культурфілософські його джерела: «Панфутуризм М. Семенка постає для свого часу оригінальним синтезом економічної концепції марксизму, культурології Шпенглера - під оболонкою дарвіністської метафорики» (Біла 2006: 144). Філософ Г. Вдовиченко надто деталізує цей ряд (див. Вдовиченко 2009: 24-25). 
цтво переходової доби» до комунізму, мистецтво «динамічне», «революційне» (Мертвопетлюйко 1919: 34).

2. Суть і перспективи футуризму окреслено так: «Надзвичайне напруженнє індівідуалізма - ось перший згусток футуризма, його перший етап. I після футуристичного індівідуалізма - слідуючий і найближчий крок - комунізм, комуна духа, запереченнє «я», футуркомуна. Так послідовно й льогічно. Футуризм переходової доби в розвитку мистецтва як такого - боротьба індівідуалізма 3 комунізмом. Змаганнє при цікавих обставинах: 1) Свідомість комунального неминучого (сучасний футурист). 2) Атавізми попереднього егоїзму (сучасний футурист). Процес одночасовий і характеризує мистецтво переходової доби - доби революції - доби зміни побутів: капіталістичного й соціялістичного» (Мертвопетлюйко 1919: 34). Отже, М. Семенко окреслює еволюцію футуризму: якщо на першому етапі футуризм несе у собі «напруження індивідуалізму», то наступний його крок веде у комунізм, комуну, заперечення «я».

3. Колосальні амбіції М. Семенка та його прибічників виявилися у проголошенні панфутуризму як пролетарського футуризму, як «останнього деструктивно-конструктивного, революційно-будівничого етапу мистецтва». М. Семенко так визначає ідейний запит на панфутуристичне вчення з позицій комуністичної культурної установки: «Час, коли теорія приходить на допомогу практиці, наспів. Тов. Ленін колись сказав, що без солідного філософічного обгрунтування пролетарського руху нам не витримати боротьби з навалою буржуазних ідей. Відсутність солідного філософічного обгрунтування революційного марксизму в галузі культури й особливо мистецтва - ось первопричини того, що тут панує жахлива розбіжність думок, і відсутність комуністичної політики в мистецтві дає значні негативні наслідки. В нашу мистецьку дійсність вливається могутній потік буржуазних, дрібнобуржуазних і анархічних ухилів, що під маркою пролетаріяту, користуючись невиразністю становища, різними засобами пролазять у пролетарське молоде тіло й труять його. Ось чому ми гадаємо, що можна викинути гасло: ми перебуваємо час, коли теорія нас урятує» (Семенко 1924б: 222).

4. При цьому М. Семенко відкидає проблему форми і змісту (що часто слугувала предметом дискусій 1920-х рр.), виводячи такі засадничі категорії нового вчення, як «ідеологія» та «фактура»: «Сучасне мистецтво переросло деякі застарілі канони естетики й теоретичні означення. До них відноситься й такий розподіл єства мистецтва, як форма й зміст. Форма й зміст - це атрибути академічні й класичні, а сучасна проблема мистецтва - футуристична й революційна 3 обов’язковим приматом ідеологічним. <..> Мистецький процес, процес творчости, має дуалістичний характер: він складається із сути зовнішньої (означимо iii хоч фактурою) і сути внутрішньої (це буде ідеологія). Ідеологія є корективний і вольовий момент у мистецтві, ідентичний з філософією доби. <..> Поняття фактури синтезоване: фактура є матеріял плюс форма плюс зміст. Кожний з елементів фактури є поняття виведене, відносне, а не абсолютне. I зміст, і матеріял, і форма $є$ атрибути відносні. Абсолютне є синтезоване поняття «фактури», i фактура разом з ідеологією створюють те, що ми називаємо мистецтвом, а для переходової доби це й буде пролетарський футуризм - панфутуризм» (Семенко 1928: 103-104). Відповідно, ідеологія виступає організаційним чинником мистецтва. 
5. М. Семенко розширює панфутуризм «теорією культів». Тут він уживав слово «культ» у значенні «система» ${ }^{6}$. Відповідно до неї, культура як «система систем» містить такі культи: релігія, мистецтво, політика, філософія, право, наука, техніка. Кожен з них - викликаний «біо-соціяльною потребою», «тимчасовий ... утилітарний чинник людського соціяльного існування». Культи динамічні, мають свій процес розвитку, але і підлягають взаємодії та впливам один на одного. Вони можуть зазнавати і радикальних трансформацій, навіть втрачаючи свою вихідну ідентичність. У цій теорії представлено аналогію між розвитком історичних формацій та культів, що мають своє «коло завершення» (зародження, розквіт і смерть). Культи $є$ суб'єктом діалектичного закону, закону конструкції та деструкції, дія якого здійснюється так: «Кожна хвиля конструкції відсуває у минуле ті сили і речі, що на цей момент занепали, здеструктували, виконавши своє конструктивне завдання в попередній відрізок історії. Кожна хвиля конструкції спадає, деструктує відносно нової хвилі, яка піднімається, при чому концентрація конструктивних елементів відбувається в деструктивній обстановці» (Семенко 1924б: 224). Розгалужений і подрібнений на течії мистецький процес кінця XIX - початку XX ст. свідчив про кризу одного 3 «культів» - мистецтва. М. Семенко назвав період перед кризою часом Великого Мистецтва (або «буржуазного мистецтва»). Внаслідок деструкції елементи, які утворювали стару систему, не зникали, а ставали будівельним матеріалом для нової системи зв'язків та функцій. Відповідно, після остаточної деструкції Великого Мистецтва його елементи мають стати «цеглинами» нового, конструктивного культу.

6. Провідний панфутурист стверджує, що комуністична культура мусить бути у цілому «конструктивна», тож з огляду на це він убачає основне завдання ідеологічної боротьби у перехідну до комунізму добу в остаточному подоланні всіх деструктивних культів, зокрема таких, як релігія та мистецтво 7 . Прогнозуючи смерть Великого Мистецтва, він зазначає, що нова система спиратиметься на раціональні, наукові принципи: «наукотехніка являє собою той культ-гегемон, що надасть відповідної тональности <... $>$. Наукотехніка стає віссю культурного фронту, яка пронизує весь стовбур суспільного існування» (Семенко 1924а: 185). Таким чином, деструктивний процес Великого Мистецтва (як суміші естетизму й патріотизму) кінцевою метою має конструкцію - нову форму творчості, організовану за принципами науки і техніки. Нова раціональна й наукова система як «основне ядро комуністичної культури» названа М. Семенком Велика Техніка. Перехідний період до неї представлений «метамистецтвом», тобто $\epsilon$ «кустарницьким етапом Великої Техніки», і означає «органічне входження деформованого мистецтва в атмосферу науки, техніки, спорту» (Трирог 1922: 2). Це була так звана «програма-максимум» панфутуристів.

8. Панфутуристи вбачали у мистецтві безпосереднього учасника перетворення суспільства. На думку М. Семенка та його прибічників, варто утилізувати «ефекти» культу мистецтва, що відмирає, до яких звикли маси. Проміжок між

\footnotetext{
${ }^{6}$ Слова «культ» $\mathrm{i}$ «система» у М. Семенка вживаються як синоніми.

7 У своїх працях дію конструкції та деструкції М. Семенко детально пояснює на прикладі релігії і прогнозує аналогічний розвиток мистецтву.
} 
деструкцією й конструкцією (переходова доба) потребує екструктивної практики. Отже, екструкція - явище «практичного» використання мистецтва в освіті та пропаганді. Поряд з іншими концептами панфутуристичної теорії («деструкція», «конструкція», «ідеологія», «фактура») вона займала маргінальне місце. М. Семенко зазначав, що «значення екструкції обмежене», «не має тенденцій розвитку»; виконуючи тимчасову функцію, «екструктивне мистецтво одвалюється, як непотрібна річ» (Семенко 1924а: 194). Реалізуючи таку практику, - зокрема при експлуатації старих (традиційних і консервативних) або при творенні гібридних форм, а також і на інтертекстуальному рівні (Біла 2006: 187), - панфутуристи вбачали ïi негативний вплив у тому, що вона віддаляє від деструктивного процесу, а значить і утворенню нового, конструктивного культу, тобто «екструкція по своїй природі ворожа конструкції» (Семенко 1924а: $194)^{8}$. Утім, необхідність застосування екструкції була продиктована низьким культурним рівнем аудиторії, який спостерігали панфутуристи під час своїх виїзних акцій-читань. Тому, наприклад, на цьому етапі перебудови мистецтва панфутуристи частіше обирають для інтертекстуальних ігор більш відомі прототексти і вдаються до більш експліцитних інтертекстуальних маркерів порівняно 3 ранішими експериментами. Тобто важливим є більш легке впізнавання широкими масами авторських маніпуляцій з відомими літературними сюжетами та образами, цитації, стилізації тощо.

9. Ще однією 3 ідейно-політичних настанов «пролетарського футуризму» став функціоналізм, який був схожий $з$ екструкцією за такою характеристикою, як утилітарність, але передбачав і елемент експерименту, новизни. Функціоналізм сприймався як переходовий, компромісний концепт, але фактично вже як частина «конструкції». М. Семенко пише: «деструкція < ..> пізніше привела до теорії й практики функціональних мистецтв» (Семенко 1930: 57). Варто зауважити, що саме цьому поняттю - функціоналізм - М. Семенко мало приділяв уваги; його більше пояснювали у «Новій генерації» інші теоретики, зокрема Л. Скрипник, О. Полторацький, П. Мельник. Функціональний підхід до творчості полягав у тому, що твір, зокрема вірш, мав «будуватися», «майструватися», відтак його структура, як і в архітектурі, мала бути залежна від функції. Така програма переводила літературу на «рельси виробничих мистецтв», на вищу еволюційну сходинку. Функціоналізм не заперечував експериментування, формальних пошуків чи новаторства, яке цінували футуристи, а також доводив практичну й ідеологічну цінність їхньої творчості ${ }^{9}$. Г. Скляренко

\footnotetext{
${ }^{8}$ Варто також згадати, що у працях Мистецтво як культ та До постановки питання про застосування ленінізму на 3-му фронті М. Семенко, поряд із екструкцією, вводить і поняття обструкції, але воно не увиразнюється, не розробляється детальніше ні в цих, ні в інших його теоретичних розробках. У зазначеному текстах подається приклад «комуністичної обструкції» на фронті боротьби з релігією: заміна релігійних свят комсомольськими. Тобто обструкція виступає демонстративною протидією, втручанням у прояви «культу» 3 метою його знищення як певної планової акції. «Але мало хто з сучасних марксистів догадується, що цей саме спосіб є якраз ранній футуризм на фронті мистецтва», - пише М. Семенко (Семенко 1924б: 228).

${ }^{9}$ О. Ільницький зазначає: «термін у чомусь нагадував хамелеона. 3 одного боку, його вживали на означення експериментального твору, який раніше, ймовірно, просто був би названий «деструктивним». 3 іншого, він також означав твір надто доступний та переобтяжений
} 
цілком слушно визначає, що у своїй теорії (зокрема щодо наповнення концептів «екструкції» та «функціоналізму») панфутуризм збігався з ідеями виробничого мистецтва та радикальним конструктивізмом. (Скляренко 2017: 80).

Отже, футуристи претендували на всеохоплюючий вплив і масштаб своїх мистецьких пропозицій. Інтерпретація панфутуризму як «метанаративу марксизму», прикладу застосування ленінізму в мистецтві, означала претензію на гегемонію в літературі. Хоча утопізм панфутуризму дуже не відрізнявся від утопізму соціалістичного мистецтва, він став об'єктом гострої критики. Радянське літературознавство вперто кваліфікувало футуризм як дрібнобуржуазну занепадницьку течію й засуджувало його представників, зокрема, за те, що вони пишуть надто загадкову, елітарну літературу (маючи на увазі їхні формалістичні експерименти), а також за пристосовництво до марксизму-ленінізму ${ }^{10}$. Натомість чимало читачів та критиків післярадянської епохи відкидають авангардну поезію через іiї політичну «лівизну», зокрема підхоплюючи, за інерцією, висловлені колись звинувачення у «самозраді» на адресу М. Семенка ${ }^{11}$.

\section{До практики}

Отже, звернемось до пізньої, лівомаркованої поезії М. Семенка 1928-1931рр., розглянемо загальні поетико-стильові домінанти художнього наповнення його збірок Сучасні вірші та 3 радянського щңоденника. Кожна містить по два цикли: перша поділена на Політичні і побутові та Полемічні вірмі й памфлети; у другій поетичні твори окремо тематично означені як Труднощі й перемоги та На штурм ударного кварталу.

політичними завданнями. Політичні обставини впливали на те, що називали функціоналізмом, звідси й певна амбівалентність, що переслідує визначення» (Ільницький 2003: 249). У деяких інтерпретаціях функціоналізм надто зближувався 3 екструкцією. Сучасна літературознавиця Я. Цимбал зауважує, що із часом дидактичне (свідомий вплив на читача, організація його думок і емоцій) і конструктивне (синтез елементів мистецтва з наукою і технікою) значення функціоналізму, яке йому надавав, наприклад, О. Полторацький, набули виразного ідеологічного акценту, зокрема у працях П. Мельника: «Щоб поезія була функціональна, вона мусить бути злободенна і наскрізь політична, щоб вона була зброєю в клясових боях 3 нашого боку барикад. Це досягається в спосіб акцентування на спрямованні твору і відповідної до цього спрямовання організації фактурного матеріялу» (цит. за Цимбал 2014: 33).

${ }^{10}$ Наприклад: «Футуризм пристосувався до радянської дійсности. Футуризм більш того, навіть встиг оголосити себе всефутуризмом, себто системою, яка «підпорядковує» собі все сучасне життя, навіть, ленінізм, який, як ми вже це бачили, являється складовою частиною панфутуризма, екструкцією в економполітиці. Це безперечно був «геніяльний» крок панфутуристів» (Сенченко 1930: 207).

${ }^{11}$ Так, В. Коряк пише: «В українській радянській літературі Тичина, Семенко перейшли шляхом вагань і шукань на позиції пролетаріяту < ..>. Футурист Семенко також відбував своєрідний шлях від суто буржуазного урбанізму, від різних Пьєро, які кохають, «задаються» і «мертвопетлюють» та містичних «Ліліт» і святих Терез, від люмпенбуржуазної анархічности через смугу деструктивних та «екструктивних» екзерсисів і заперечення пролетарської літератури, до цілковитої капітуляції і зречення своїх власних концепцій футуризму - «кверо», «пан», «комункульт», «новогенераційства»» (Коряк 1932: 13). 
Назви цих циклів уже є прикметними 3 погляду тогочасної вербальної практики, що розгорталася у напрямку «політика (мова влади) - публіцистика - поезія». У літературному процесі тієї доби, як зазначає Т. Коваленко, увиразнюються «інтердискурсивні зв'язки з дискурс-будовою радянської політики» (Коваленко 2015: 75). Відповідно, й у зазначеному поетичному доробку М. Семенка знаходимо багатий репертуар лексики та кліше з політичного та публіцистичного дискурсів: партійні фронти, лямпочка Ілліча, ясна комуністична позиція, більшовицька Івардія, більшовицькі темпи, соціялістичні рейки, рядянський горн, грунт соціялізму, револючійний грунт, револющійний наказ, революиійна кров, револючії сини, покоління нове революціонерів-будівників, комуністичне/радянське суспільство, діялектичний матеріялізм, пролетарська самомобілізація, шкідницька контрреволючуія, клясові бої, комсомольиі ростуть, бий ворогів революиї, ударна робота, ударна бригада, індустріяльна база, індустріялізачія, колективізація, електрифікація, n'ятилітка/n'ятирічка, гасло, пролетаріят, обивателі, інтервенти, опортуністи, петиція.

Також тут з'являються актуальні абревіатури ( або транскрибування абревіатур): ДВУ - Державне видавництво України; ФЗУ - Фабрично-заводське учнівство; ВЧК - Всероссийская чрезвычайная комиссия (по борьбе с контрреволюцией и саботажем), ОДПУ-Органи державного політичного управління; eH-Ka-O (тобто НКО) - Народний комісаріат освіти; $y-e c-e p-e p$ (тобто УСРР) Українська Соціалістична Радянська Республіка.

Разом $з$ тим, кількісно бідною на сторінках цих збірок представлена така стилістична особливість попередньої Семенкової творчості, як продукування оказіоналізмів. Виявлені тут авторські новотвори є експресіями переважно на актуальні того часу явища: вапліта, хвильовенко, хвильовиста одвертість, жертвопісні, тисячоспівний рот, продинамітині береги; маленька мечка (від слова Мекка); червонопрапорний ленінський комсомол; простір нив внизу колгоспиться; скучно мені, бульйонно; ми - найдіялектичніші скрізь; окомсомолить молодь на 100. У вірші Незрозуміло, кривдно, але - факт натрапляємо на цілу колонку оказіоналізмів, котра водночас $є$ цікавим прикладом градації як стилістичної фігури, що через посилення засобів художньої виразності сприяє зростанню емоційно-смислового ефекту: «Hi! / Досить незнайкографiї! / » ліньографії! / » наплюйкографії! / » заплющзочіграфії! / » зневагографії! / » неуко-

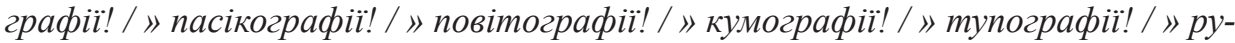
комахографіï!» (Семенко 1931: 120).

Інші засоби вираження експресивності, зокрема «непоетизми», тобто лайливі слова та подібну емоційно забарвлену лексику з негативною конотацією, зустрічаємо лише у Сучасних віршах: стерво, каюк, тупоумство, контреволюційна масова сволоч, командирований писок, валюти чортма, онанізм фокстроту.

У обох збірках немає жодного вірша, де не був би поставлений знак оклику, більше того, є вірші, утворені лише з окличних речень, наприклад Війна війні!: «-Війна війні! - / стріляти вмій у / цүіль! / - Війна війні! - / Вивчай протигаза / маску! / - Війна війні! - / готуйсь, червоноармій- / изі! / Хай живе / війна / громадянська!» (Семенко 1932: 67). Такий окличний імператив виступає частовживаною конструкцією експресивного синтаксису у пізній Семенковій творчості. 
Домінантними темами творів, уміщених у зазначених збірках, $є$ такі: динаміка будівництва соціалістичного суспільства; титанічні змагання людини 3 природною стихією; заклик до боротьби із ворогами комунізму; наукова організація праці; роль поета у розбудові сучасного комуністичного суспільства. Провідна ідея більшості творів - ідея радянського прогресу. Для прикладу: «Hi вічною ніччю, ні літом, / як сонце проходить свій круг, - / не спинить індустріі літу / вакханалія крижаних хуг» (Північ й індустрія); «Ожсили степи запорізькі / на скелі схилився кран - / електрична Україна близько / $і$ їі иентр - / Дніпрель-стан» (Дніпрельстан 1928); «Наш шлля - илях комунізму! / Наше сьогодні - вперед!» (Богема, алкоголь, соиіялізм) (Семенко 1931: 22, 32, 33). Отже, на ідейно-тематичному рівні цих творів, як і в панфутуристичній маніфестології, послідовно проступає радянська риторика й ідеологія.

Як зазначає А. Біла, екструктивна практика представників «Нової генерації» полягає в актуалізації впізнаваних для читача літературних форм, що передбачає: часткове звернення до канонічних жанрових форм, базованих на типово реалістичних композиційних принципах; творення гібридних, художньо-публіцистичних форм (вірш-промова, агітаційний вірш, вірш-репортаж); інтертекстуальність (Біла 2006: 187, 192).

Досить виразними у поезії М. Семенка 1928-1931 рр. є саме художньо-публіцистичні гібриди, зокрема вірші-агітації, просякнуті прагненням впливати на громадську активність населення через фіксацію програмних ідей та гасел, що очевидно, наприклад, у таких уривках: «Bid темпів, / від сталінського завдання / не відступимо ні на крок!» (Безпартійні); «Не знижуйте волі! / Не спускайте рук! / Перед третім напружтесь - / металіст, / шахтар! / В усі країни світу віадук - / чотирнадиятого Жовтня удар!» (Жовтня удар); «Без науки немає поступу, / без техніки - не бачить соиіялізму, / без напору - не догнать, не перегнать ніколи. / Штурмом візьмем гору! / Плазуни хай лізуть! / Для нас / існують / револючійні радянські школи!» (Револючія і культура) (Семенко 1932: $45,63-64,77)$. Перший наведений уривок дублюється в іншій, чотирирядковій поезії Гасло, що є лаконічнішим варіантом агітаційного вірша, власне, віршем-гаслом: «Бригадою вдарною станемо / на варті вирішного року. / Від темпів і соизавдання / не відступимо ні кроку!» (Семенко 1932: 20).

Назви багатьох творів часто схожі назаголовкигазетних рубрик:Дніпрельстан 1928, Авіачія, Техніка, Бавовона, Сівба, С.-Г., ФЗУ, Транспорт, Постачання й розподіл, Зимовий відпочинок, Абхазія, Кавказ тощо. Такі вірші-репортажі, у яких фіксується інформація про поточні події радянського життя, часто подібні за структурою. Вони, як правило, містять три частини, зокрема зауваження певної проблеми, перелік трудових успіхів, якими ця проблема долається, та заклик до дії: «Постачання й розподіл - / важно й дошкульно. / Контрреволючія / по иъьму б'є: / i шкідник, / і несвідомий робітник, / $і$ базарні всякі «кумушки». / От і виходить, що скоро буде / «світопреставлєніє». / Машинне господарство / реконструкиія організує, / перевага колгоспів / по труднощах б’є. / Вже иьього року / працюватимем / не всує, / якщо не задовольнятимемось / тим, що є. / Вивчайте пляни / нашого / уряду. / Кожну дрібниџю / й загальний / плян. / Тоді ходитимеш / не такий похмурий, - / становись / в ударні лави / працюючих громадян!» (Постачання й розподіл) (Семенко 1932: 40-41). 
Також тут, серед художньо-публіцистичних поетичних творів, які підпадають під гібридну назву вірш-промова, можна виокремити спрямовані проти «контрреволюційної масової сволочі», «стерва на радянській Україні» та «капіталістичного редуту» вірші-інвективи, сповнені гнівними й пафосними закликами: «Випотрошить саботажників - / час / час!» (Про шкідницьку наволоч); «A петлюрівцям і поминальникам - / смерть!» (Арсенал) (Семенко 1931: 29, 98); «Робітникам - життя, / фашистам - смерть!» (Батьківщина) (Семенко 1932: 30). Як своєрідний підвид віршів-промов, у якому акцентовано повідомлення про виконані завдання, пророблену роботу, можна окремо визначити вірші-звіти. Ось особливо показові фрагменти таких віршів: «Партія / розв’язує проблему кадрів. / В країні / тисячі нових підприємств. / Нами / одкрито / нові надра / під вий / опортуністичних скарг / і ремств» (Проблема кадрів); "1930го / покінчили / з зерновою проблемою, / 1931-й- / вирішує з м'ясом / для трудящзих всіх. / Країна / прац̧ює / пляново й організовано. / Поступово / збуваємось / різних проблем» (Хліба і м'яса) (Семенко 1932: 14, 39).

У вже процитованих тут фрагментах спостерігається така важлива характеристика Семенкової поезії пізнього періоду, як конструювання поетичної реальності через акт «колективного» мовлення, тобто часта поява «ми» як ліричного суб'єкта, виразника збірних почуттів і прагнень. Такий суб'єкт відповідає дискурсивним практикам радянського суспільства, в якому індивідуальне нівелювалося суспільним, а підкреслена приналежність до одностайної спільноти віталася як запорука побудови світлого комунізму. Отже, тут у М. Семенка простежується така загальна характеристика авангардного мистецтва, як демонстрація вищого рівня групової свідомості.

У Сучасних віршах жанрово вирізняється текст із назвою Гасла до туристських книжск (ДВУ). Сьогоднішній читач, приналежний до споживацького суспільства, зауважить його як вірш-рекламу. Цей римований рекламний матеріал, наче написаний на замовлення ДВУ ${ }^{12}$, складається 3 восьми пронумерованих дворядків, які не можна назвати вдалими ні щодо ритміки, ні щодо лексичного наповнення: «3. Без книжки подоріж і взагалі туризм - / по-моєму гірше за всякий фашизм»; «4. Хороша книга - туристові брат. / В ДВУ перед поӥздкою можна брать»; «8. Не будь халтуричиком, будь туристом! / Їдеш у подорож прочитай книжку» (Семенко 1931: 81).

Як уже зауважувалося, важливими в екструктивній практиці були інтертекстуальні зв’язки. Цікаво, що М. Семенко у вірші Наше життя і література фактично вказує на сутність нині загальновідомого явища інтертекстуальності: «Уже 1 міл. 80 тисяч днів / поет перефразовує поета / аж до / нині» (Семенко 1931: 39). Відомий панфутурист відсилання до текстів попередників використовує переважно задля пародійного ефекту.

Цілком логічно, що з погляду інтертекстуальності він найбільше експлуатує культовий шевченківський текст, який лишає мнемонічний слід в українському

12 ДВУ - Державне видавництво України, що діяло з 1922 р. У 1930 р. на основі ДВУ утворене ДВОУ - Державне видавниче об'єднання України, яке діяло до 1934 р. й об'єднувало низку видавництв (Бондарчук 2004). Са́ме ДВОУ є видавцем Семенкових збірок Сучасні вірші, 3 радянського щоденника, Міжнародні діла. 
суспільстві ${ }^{13}$. Назва Семенкової поезії Тяжко, важко в світі жити - алюзія 3 віршем Т. Шевченка Думка, що починається цими словами. У Шевченка - нарікання на тяжку долю бідняка (у фольклорній стилістиці), а у Семенка перелік чуток про важкі дні в економіці та побуті радянського суспільства, що закінчується абсурдним «кажуть, цьього року / не розтане сніг...», переведений в оптимістичне русло утвердження ідеї - «ми в комунізм ідем / не / спиняючись!» (Семенко 1932: 10-11). У довгій назві вірша Конкретна пропозиція до всіх літератури, мистецттва й науки робітників, щзо їх НКО чи інші відповідні установи мають відряджати у закордонну поїзку вбачається ремінісценція, точніше відтворення ритмічно-синтаксичної структури назви патріотичної поеми-послання Шевченка I мертвим, і живим, і ненарожденним землякам моїм в Украйні і не в Украйні моє дружнєє посланіє. I тут у Семенка переважає пародійний пафос. Загальновідомому шевченківському «I чужому научайтесь, / Й свого не иурайтесь» на початку Конкретної пропозииії... протиставляється «серйозно-іронічне» звернення: «Товариші! /Говорю серйозно: без европ нам - / як попам без / душі: / обійтись ніяк не можна» (Семенко 1931: 46), - після чого в іронічній формі пропонується раціонально витрачати валютні кошти, виділені на відрядження. Також відома шевченківська цитата, - слова, якими починається поема великого Кобзаря «Кавказ», - $є$ назвою і початком Семенкової поезії За горами гори: «За горами гори, / хмарами повиті, - / чорні, / сірі, / білі з відтінками». Таке післяцитатне уточнення кольорів налаштовує на іронічне забарвлення наступних рядків. У Шевченка - показ страждань поневолених народів Кавказу, викриття загарбницької політики Російської імперії, у Семенка ж - «фортеці розбиті» й «історією згризені кавказькі береги» на знак глузування 3 величі минулого самодержавства, а в кінці ідилічна радянська картина: «Вулицями / з прапорами ходять лави / школярів, / піонерів робітничі раті» (Семенко 1932: 85).

Також у Сучасних віршах слід відзначити Гімн хліборобів-гетьманизів, написаний Семенком у Берліні 1929 р., під час свого першого відрядження у Свропу. Він є пародією на текст П. Чубинського Ще не вмерла України ні слава, ні воля, який є гімном сучасної України, а також у 1917-1920 рр. був державним гімном УНР та Української держави гетьмана Павла Скоропадського, який після зречення влади перебрався до Берліна. Текст Семенка починається аналогічним до пародійованого вірша рядком: «Ще не вмерли пшениия $і$ жито», - і написаний як заклик прибічника гетьманату до братів-однодумців. Сатиричний ефект автор створює, зокрема, через варіації останнього рядка у рефрені: «сміливо у похід за батьківську матню!», «за сорочку й свитку, за рідну матню!», «за гетьмана-пана, за його машну!» (Семенко 1931: 14).

3 усіх текстів, представлених в аналізованих нами збірках, найбільше М. Семенка періоду кверофутуризму нагадує Повема ${ }^{14}$ про те, як повстав

${ }_{13}$ Недаремно повну збірку своїх поетичних творів 1910-1922 рр., видану 1924. р., М. Семенко назвав Кобзарем, зухвало пропонуючи читачам нову «українську Біблію» як альтернативу Шевченковій збірці з XIX ст.

${ }^{14}$ Повема - неологізм М. Семенка, утворений на основі поєднання слів «повість» $\mathrm{i}$ «поема». Насправді ж за жанром цей твір є драматичною поемою. 
cвim $i$ загинув Михайль Семенко. Як зазначає О. Полторацький, соратник М. Семенка по перу, цю драматичну поему під назвою Континенти Семенко закінчив пізніше (містила 5 частин), але вона так і не була опублікована, текст був утрачений (Полторацький 1966). Це була пародія на націоналізм, провінціоналізм, вузькість мислення, одна $з$ найдотепніших сатир автора. Повема... являє собою пустопорожні діалоги членів вигаданого «всеукраїнського відділу міжнародного клубу винахідників, ексцентриків і міжпланетарної комунікації», які займаються вивченням минулих епох у машині часу, керованій Семенком. 3 ним подорожують у часі Д. Донцов, В. Винниченко, Інтелігент, Єпископ і Дід. У мандрах вони зустрічаються з Печерною людиною і сперечаються, чи ця людина є українцем.

Семенків кверофутуристичний почерк у Повемі... проступає у таких прийомах. 1) Зворотний синтаксис: «Що мабуть изілий рік / Спати / Дадуть / Не»; "Одсунутися / Туди / В куточок / Можна / Разі / Крайньому / В »; «Тут уже / До жартів / Не». 2) Повторення коротких (як правило, однослівних) речень - «ехо»: «С и и с к о n: / Ма. / Ма. / Ма. / Д о н из о в: / Але докази. / Докази. / Докази. / Д $і$ д: / Ocb. / Ocb. / Ocb». 3) Усічення слів (реципієнт їх реконструює): «Від чорного моря пішли на за...» (реконструкція - «захід»); "Чого там іше вони не ба...» (реконструкція - «бачили»); «Чи не могли б ви зачека́? » (реконструкція - «зачекати»). 4) Розривання слова і перенесення його частини на інший рядок: «Блукав парнаською горо / ю...»; «У 20 років уже старига / ном я»; "Сем ен ко: / Слу / хаємо - / Слу / хаємо - / Слу / хаємо».

Фантазуючи про діалоги героїв, серед яких і вагомі історичні особи, автор надає читачеві можливість виявити деякі інтертекстуальні маркери. Зокрема, через використання чужого оказіоналізму: "Д $і$ д: / Невже весна? / Красна? / Закосичена?..» (Семенко 1931: 73), - який є слідом вірша П. Тичини Арфами, арфами... («Йде весна / Запашна / Квітами-перлами / закосичена»). Але М. Семенко ставить тичинівський оказіоналізм у зневажливий контекст: у деяких героїв капає з носа, на основі чого Дід робить припущення про прихід весни.

Якщо під приціл Семенкової сатири у збережених уривках Повеми... поетичний геній раннього Тичини потрапляє «між іншим», то в недолугих репліках Донцова та Винниченка автор послідовно і щиро висміює крайнощі націоналізму, долучаючи, зокрема, і деякі побічні факти, зокрема щодо графоманства зараз визнаного видатним історика й політика: «Що то є-печерна людина? / Про неї ж / і наш Михайль Грушевський / у 148-му томі своєї «Історії украйнського народу» / на 3845-ій сторінияі (другий стовпец̧ь) говорить» (Семенко 1931: 75). «Всякий буржуазний націоналізм в усіх його проявах був запеклим ворогом Семенка, так само як і гітлеризм ${ }^{15}$, який в останні роки його життя підняв голову в Німеччині», - зауважує О. Полторацький (Полторацький 1966). Повема... є тому підтвердженням. І слід зазначити, що іiі антинаціоналістичний характер виявляється не за рахунок присутності тут радянського пафосу. Питання національного у футуристів не було на часі через «вищі» мотиви. Г. Скляренко слуш-

${ }^{15}$ Цю думку, зокрема, підтверджують Семенкова поема «Німеччина» (1933-1936) та вірші «Промова Гітлера» й «Інтерв’ю à la Гітлер» (1933). 
но узагальнює: за довгу історію свого існування футуристичний рух активно влився в русло нового радянського мистецтва, інтегрував у собі ідейні спрямування його «лівого» крила, де питання української незалежності розчинялися в інтенціях пролетарської культури (Скляренко 2017: 76).

Торкаючись традиційної теми ролі митця та мистецтва у суспільному житті, кожен митець, перш за все, окреслює власні пріоритети. М. Семенко у своій панфутуристичній творчості позиціонує митця як бійця та агітатора, для якого завдання боротьби й пропаганди стають першочерговими. Відповідно, процес пролетаризації культури, за М. Семенком, передбачає активне «втручання» публіцистики, а також науково-технічних принципів у літературу: «Худнуть $і$ блякнуть / письменники і поети, / «генії» ізольованої / кабінетної тиші. / Хто не встигає / сьогодні з газетою, / той для бабусі своєї пише» (Ударники - в літературу!) (Семенко 1932: 61); «Поети, зривайте клясики метр! / Поети, иляхів наших - інші темпи! / Нестрашні для марксиста історії нетри! / Поети, індустріялізуйте джунглі і степ!» (Наме життя й література) (Семенко 1931: 39).

Т. Коваленко виокремлює той факт, що у рамках радянської ідеології, яка наступала в літпроцесі 20 -х років минулого століття, віталися самокритика письменника, визнання «ухилів» чи «помилок» (Коваленко 2015: 75). Відповідно, для «радянського» поета мало було просто почати писати інакшу поезію, яка б уже відповідала тому соцреалістичному канону, що остаточно закріпився 3 1930-х років, вважалася не зайвою і присутність каяття. У М. Семенка цього не було, навіть навпаки, у Сучасних віршах натрапляємо на такі рядки: «B своєму минулому я не / каюсь / i закидаю вгору більшовищький кран» (Куркулі й фашисти); «Не буду картати і каятися / за кожний свій / рядок. / Я не відповідаю за минулі / епохи. <... / Я - / Еверест на тлі ваших підсліпуватих огнів, / блох $і$ канарок, - / не викинеш / у прислів 'ї (Канарки і я) (Семенко 1931: 87, 89-90). Останні зацитовані слова - свідчення самозвеличення, акцентування власної значущості, у чому впізнається ранній, «кверофутуристичний» Семенко.

\section{Підсумкові спостереження}

Сучасні дослідники, які займаються «реабілітацією» та «реставрацією» українського авангарду ${ }^{16}$, наголошують, що твори тодішньої літератури не могли розвиватися поза ідеологічними маніпуляціями та життєперебудовчими програмами. Дух конформізму щодо радянської системи, зрештою, був характерний не лише для авангардистів, «після встановлення радянської влади всі мистецькі об'єднання та угруповання у своїх публічних деклараціях програмно підкреслювали як свою лояльність щодо радянської влади, так і щире бажання створювати нове, ідеологічно витримане пролетарське мистецтво» (Скляренко 2017: 76). О. Коцарев та Ю. Стахівська вважають: «Віра авангарду в перетворення світу за допомогою слова нагадує певний месіанізм. I саме він спричиняється до паралелей із тоталітаризмом, який першочергово прагне перетворення

16 На нашу думку, тут слід виокремити такі прізвища, як Г. Черниш, М. Сулима, О. Ільницький, А. Біла, О. Коцарев, Ю. Стахівська, Г. Скляренко, Я. Цимбал, Л. Якимчук та ін. 
світу тим же таки словом - проголосити, переконати, посвятити, наказати і заборонити. Футуризм і фашизм в Італії, сюрреалізм і комунізм у Франції. <...> Але тоталітаризм «тисне» і на мистецький авангард, якнайбільше прагне його (як конкурента) собі уподібнити, запозичити його мистецькі методи» (Коцарев та ін. 2018: 22).

Діяльність багатьох літературних угруповань, що утворилися 3 появою Української Соціалістичної Радянської Республіки, відповідала духу та принципам будівництва нової держави. Завдяки увиразненню у творчості панфутуристів реалістичних тенденцій згодом «соцреалізм закріпив і по-своєму використав цілу низку практичних досягнень футуризму» (Біла 2006: 183), відповідно, й «авангардні принципи утопічної майбуттєвості та життєбудування стали основою для соцреалізму» (Коцарев та ін. 2018: 22). Як не парадоксально, з одного боку, теоретизування М. Семенка фактично сприяли легітимізації пізніше запровадженого соцреалізму, що став «єдино правильним методом», а 3 іншого - са́ме цей метод посприяв винесенню смертного вироку нескромному «Евересту» тодішньої літератури. Л. Якимчук, відштовхуючись від архівних матеріалів, зазначає, що 1934 року на першому з’ізді Спілки письменників, де було проголошено соцреалізм, М. Семенко не побоявся у колуарах, маючи дорадчий голос, відверто говорити про те, що все це йому не подобається. Ця вся інформація є в донесеннях, і саме через це його життя 1937 року закінчилося розстрілом (Якимчук 2012).

Панфутуризм як авангардна культурфілософська концепція на основі осмислення марксизму-ленінізму теоретично охоплював такі чотири стадії перебудови мистецтва, як деструкція, екструкція, функціоналізм, конструкція, серед яких друга та третя були компромісними, перехідними від деструктивного процесу над «Великим Мистецтвом» до конструювання нової форми творчості на науково-технічних засадах. Відповідно, естетизму відмираючого «Великого Мистецтва» панфутуристи протиставили доцільність, дієвість, практичність нового конструктивного «культу».

Необхідність утилітарного використання твору, про яку теоретизував М. Семенко, вбачається виявом щирих переконань митця, а не навіяним якимись кон'юнктурними міркуваннями рішенням. Я. Савченко, сучасник М. Семенка, ще в період «піку» футуризму вказував на примат теорії як характерної ознаки його творчості: «Приймаючи світ теоретично і може навіть психологічно в певній «футурній» концепції, він, Семенко, при спробах інтерпретувати ту концепцію у формі образів і фарб, зараз же виявляє слабі сторони свої, яко художника, інакше кажучи він, яко художник, має замало сил для відповідного ствердження і санкціонування тих етапів, які пройшов Семенко яко теоретик-футурист» (Савченко 1918: 43).

\section{Висновки}

При дослідженні ідейно-тематичних та жанрових пріоритетів у поетичних збірках М. Семенка Сучасні вірші та 3 радянського щзоденника, виявлено, що тут превалюють тема розбудови сучасного комуністичного суспільства, ідея радянського прогресу та художньо-публіцистичні гібриди (вірш-агітація, 
вірш-репортаж, вірш-промова, вірш-звіт). Домінантними поетико-стильовими особливостями $є$ політична тенденційність, публіцистичність, радянська риторика, іронія, сарказм, інвектива, окличний імператив, «ми» як ліричний суб’єкт, інтертекстуальність тощо. Зважаючи на положення теорії панфутуризму як контексту цих творів, зауважимо, що футуризм Семенка був явищем концептуальним: Семенко-митець певною мірою «наздоганяв» настанови та прогнози Семенка-теоретика. На нашу думку, його пізню поезію можна трактувати як намагання проілюструвати теоретичні концепти екструкції та функціоналізму, а отже, і як ознаку певної послідовності, поступовості, стадіальності - тобто градації! - авангардної творчості цього митця.

\section{Використана література}

Біла, Анна. Український літературний авангард: пошуки, стильові напрямки. Київ: Смолоскип, 2006.

[Bìla, Anna. Ukraïns'kij literaturnij avangard: pošuki, stil'ovì naprâmki. Kiïv: Smoloskip, 2006]

Бондарчук, Петро М. «Державне видавництво україни». Енциклопедія історії України: Т. 2: Г-Д /Редкол.: В.А. Смолій (голова) та ін. Київ: Наукова думка, 2004. <http://www.history.org.ua/?termin=Derzh_vydav_vo_Ukrainy > 14.03.2021.

[Bondarčuk, Petro M. «Deržavne vidavnictvo ukraïni». Enciklopediâ ìstoriï Ukraïni: T. 2: G-D / Redkol.: V.A. Smolij (golova) ta ìn. Kiïv: Naukova dumka, 2004. <http://www. history.org.ua/?termin=Derzh_vydav_vo_Ukrainy $>14.03 .2021]$

Вдовиченко, Георгій. «Концепція «пролетарського футуризму-панфутуризму» М. Семенка: філософські засновки «теорії культів» і «теорії об’єктивних аналогій»»». Гуманітарні студії : КНУ ім. Т. Шевченка 5/6, 2009: 23-34.

[Vdovičenko, Georgìj. «Koncepciâ «proletars'kogo futurizmu-panfuturizmu» M. Semenka: filosofs'kì zasnovki «teoriï kul'tìv» ì «teoriï ob'êktivnih analogijj»». Gumanitarnì studiï : KNU ìm. T. Ševčenka 5/6, 2009: 23-34]

Ільницький, Олег. Український футуризм (1914-1930). Львів: Літопис, 2003.

[İl'nic'kij, Oleg. Ukraïns'kij futurizm (1914-1930). L'vìv: Litopis, 2003]

Коваленко, Тетяна. «Декларації та реальність: дискурсивна специфіка українських літературних маніфестів 1920-х рр.». Науковий вісник Східноєвропейського національного університету ім. Лесі Українки. Філологічні науки. Літературознавство 8, 2015: 72-79.

[Kovalenko, Tetâna. «Deklaraciï ta real'nìst': diskursivna specifika ukraïns'kih literaturnih manìfestìv 1920-h rr.». Naukovij vìsnik Shìdnoêvropejs'kogo nacìonal'nogo unìversitetu ìm. Lesì Ukraïnki. Fìlologičnì nauki. Lìteraturoznavstvo 8, 2015: 72-79]

Коряк, Володимир. «По сторінках історії української жовтневої літератури». За марксо-ленінську критику 11, 1932: 5-15.

[Korâk, Volodimir. «Po storìnkah ìstoriï ukraïns'koï žovtnevoï literaturi». Za marksolenìns'ku kritiku 11, 1932: 5-15]

Коцарев, Олег, Стахівська, Юлія. «“Я трублю зеленою грушкою!”: Деякі попередні зауваги». [У:] Українська авангардна поезія (1910-1930-і роки): Антологія / Упор. О. Коцарев, Ю. Стахівська. Київ: Смолоскип, 2018: 17-38.

[Kocarev, Oleg, Stahìvs'ka, Ûliâ. «“Â trublû zelenoû gruškoû!”: Deâkì poperednì 
zauvagi». [U:] Ukraïns'ka avangardna poeziâ (1910-1930-ì roki): Antologiâ / Upor.

O. Kocarev, Û. Stahìvs'ka. Kiïv: Smoloskip, 2018: 17-38]

Кузьменко, Володимир I. (ред.) Історія української літератури XX - поч. XXI ст. Навч. посіб., Т. 1. Київ: Академвидав, 2013.

[Kuz'menko, Volodimir İ. (red.) İstorìa ukraïns'koï lìteraturi HH - poč. HHÌ st. Navč. posìb., T. 1. Kiïv: Akademvidav, 2013]

Павличко, Соломія. «“Мистецтво”, або авангард як антимодернізм». [У:] Павличко, Соломія. Дискурс модернізму в українській літературі. Київ: Либідь, 1999, 182 190.

[Pavličko, Solomîa. «"Mistectvo”, abo avangard âk antimodernìzm». [U:] Pavličko, Solomiâ. Diskurs modernìzmu v ukraïns'kìj lìteraturì. Kiïv: Libìd', 1999, 182-190]

Полторацький, Олексій. «Михайль Семенко та “Нова генерація”». Вітчизна 11, 1966. $<$ https://md-eksperiment.org/post/20160519-mihajl-semenko-ta-nova-generaciya $>$ 10.03.2021.

[Poltorac'kij, Oleksìj. «Mihajl' Semenko ta "Nova generaciâ"»». Vitčizna 11, 1966. <https://md-eksperiment.org/post/20160519-mihajl-semenko-ta-nova-generaciya> 10.03.2021]

Савченко, Яків. «Михайло Семенко. “П’єро задається”». Літературно-критичний альманах 1, 1918: 28-45.

[Savčenko, Âkìv. «Mihajlo Semenko. "P'êro zadaêt'sâ"». Lìteraturno-kritičnij al'manah 1, 1918: 28-45]

Сенченко, Іван. «У парках зблідлих фантазій (Епітафія)». Політфронт 8-9, 1930: $177-210$.

[Senčenko, İvan. «U parkah zblìdlih fantazìj (Epìtafiâ)». Polìtfront 8-9, 1930: 177-210]

Скляренко, Галина. «Футуризм в Україні: етапи та спрямування». Студії мистецтвознавчі 2, 2017: 63-82.

[Sklârenko, Galina. «Futurizm v Ukraïnì: etapi ta sprâmuvannâ». Studï mistectvoznavčì 2, 2017: 63-82

Цимбал, Ярина. «Функція versus емоція: трансформації жанру балади у творчості “Нової генерації” Літературознавчі обрії 21, 2014: 31-37.

[Cimbal, Ârina. «Funkciâ versus emociâ: transformaciï žanru baladi u tvorčostì "Novoï generaciï”». Lìteraturoznavčì obriï 21, 2014: 31-37]

Якимчук, Любов. «Михайль Семенко: від футуризму до тероризму». ЛітАкцент, 27.12. 2012. <http://litakcent.com/2012/12/27/myhajl-semenko-vid-futuryzmu-doteroryzmu/> 12.01.2021.

Âkimčuk, Lûbov. «Mihajl' Semenko: vìd futurizmu do terorizmu». LìtAkcent, 27.12. 2012. $\quad<$ http://litakcent.com/2012/12/27/myhajl-semenko-vid-futuryzmu-doteroryzmu/> 12.01.2021]

\section{Джерела}

Мертвопетлюйко П. [Семенко М.] «Мистецтво переходової доби». Мистецтво 2, 1919: 33-34.

[Mertvopetlûjko P. [Semenko M.] «Mistectvo perehodovoï dobi». Mistectvo 2, 1919: 3334]

Семенко, Михайль. «До постановки питання про застосування ленінізму на 3-му фронті». Червоний шлях 11-12, 1924a: 169-201. 
[Semenko, Mihajl'. «Do postanovki pitannâ pro zastosuvannâ lenìnìzmu na 3-mu frontì». Červonij šlâh 11-12, 1924a: 169-201]

Семенко, Михайль. 3 радянського щоденника. Поезії 1930-1931. Харків: ДВОУ, ЛiM, 1932.

$<$ https://elib.nlu.org.ua/view.html?id=8672> 28.06.2021.

[Semenko, Mihajl'. Z radâns'kogo ŝdennika. Poezii 1930-1931. Harkìv: DVOU, LìM, 1932. <https://elib.nlu.org.ua/view.html?id=8672> 28.06.2021]

Семенко, Михайль. «За консолідацію пролетарських сил в українській літературі». Нова генерація 3, 1930: 57-58.

[Semenko, Mihajl'. «Za konsolìdaciû proletars'kih sil v ukraïns'kìj lìteraturì». Nova generaciâ 3, 1930: 57-58]

Семенко, Михайль. «Мистецтво як культ». Червоний шлях 3, 1924б: 222-229.

[Semenko, Mihajl'. «Mistectvo âk kul't». Červonij šlâh 3, 1924b: 222-229]

Семенко, Михайль. «Постановка питання в теорії мистецтва переходової доби (Панфутуристичний маніфест)». [У:] Лейтес, Александр М., Яшек, Микола Ф. Десять років української літератури (1917-1927). У 2 т. Т. ІІ. Харків: ДВУ, 1928: $100-106$.

[Semenko, Mihajl'. «Postanovka pitannâ v teorï mistectva perehodovoï dobi (Panfuturističnij manìfest)». [U:] Lejtes, Aleksandr M., Âšek, Mikola F. Desât' rokìv ukraïns'koï lìteraturi (1917-1927). U 2 t. T. İİ. Harkìv: DVU, 1928: 100-106]

Семенко, Михайль. Сучасні вірші. Харків, Київ: ДВОУ, ЛіМ, 1931. <https://findbook. in.ua/books/suchasni-virshi> 28.06.2021.

[Semenko, Mihajl'. Sučasnì vìršì. Harkìv, Kiïv: DVOU, LìM, 1931. <https://findbook. in.ua/books/suchasni-virshi> 28.06.2021]

Трирог М. [Семенко М.] «Что такое деструкция». Катафалк искусства 1, 1922: 2.

[Trirog M. [Semenko M.] «Čto takoe destrukciâ». Katafalk iskusstva 1, 1922: 2]

Јулија Драгојловић

\section{КА ПИТАҢУ О (ДЕ)ГРАДАЦИЈИ У ПОЕЗИЈИ ДРУГА СЕМЕНКА}

\section{Резиме}

Каснијем стваралаштву Михајља Семенка посвећено је мало пажње, јер се у њему уочава песниково окретање од футуристичких експеримената према пракси социјалистичког реализма, односно својеврсна деградација, с тачке гледишта савременог реципијента који има могућност да посматра специфичност целокупног књижевног процеса у Украјини током последњих сто година.

У овом раду представљен је покушај да се стваралаштво Михајља Семенка каснијег периода сагледа у контексту теорије патфутуризма коју је предложио песник и његови следбеници. Теорија је обухватала такве фазе обнове уметности као што су деструкција, екструкција, функционализам и конструкција. Деструктивни процес «Велике уметности» (као мешавине естетизма и патриотизма) за крајњи циљ имала је конструкцију, односно нову врсту уметности организовану на принципима науке и технике. Екструкција («практично» коришћење уметности у образовању и пропаганди) и функционализам (спој утилитаризма и новине) у овом процесу представљале су прелазну, компромисну фазу. 
У раду се разматрају идејно-тематски и жанровски приоритети, као и поетско-стилске доминанте Семенкове поезије, настале у периоду од 1928. до 1931. године, који указују на то да је Семенков футуризам био појава концептуална: може се рећи да је Семенко као уметник «сустизао» прогнозе Семенка као теоретичара. По нашем мишљењу, његово касније стваралаштво може се интерпретирати као покушај илустровања теоретских концепата екструкције и функционализма, односно као ознака одређене градације, фазности, стадијалности авангадрног стваралаштва овог уметника.

Кључне речи: Михајљ Семенко, поезија 1928-1931 године, теорија панфутуризма, екструкција, функционализам. 